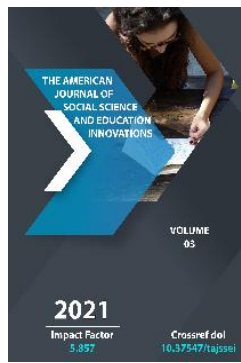

\title{
From The History Of Rhetoric (Ortaorian Skill) Of The Ancient East
}

\author{
Aripova Aziza Khasanovna \\ PhD, Associate Professor, Specialized Branch Of Tashkent State University Of Law, Head Of \\ The Department Of General Education, Tashkent, Uzbekistan
}

Journal Website:

https://theamericanjou

rnals.com/index.php/ta

jssei

Copyright: Original content from this work may be used under the terms of the creative commons attributes 4.0 licence.

\section{ABSTRACT}

This article tells about the historical forms of the oral living word in the ancient East, about such forms as dabirlik (the writers and readers of the state correspondence), xatiblik (speakers of religious, political speech), and muzakkirlik (speakers of religious and moral issues). All types of rhetoric (oratory art) that were used by scholars of orientalism.

\section{KEYWORDS}

Culture, speech etiquette, art, of the realm of speech, dabirlik, xatiblik, muzakkirlik.

\section{INTRODUCTION}

Speech culture and public speaking skills have long been a social phenomenon. In ancient Greece, this doctrine was theoretically grounded: rhetoric (the art of speaking) was considered a masterpiece of high oral art, along with epics, poetry, dramas, music, and other works of art. In the history of Central Asian culture, too, dealing with the problems of speech culture and methodology has existed for a long time and has its own peculiarities. The famous Turkologist Mahmud Kashgari's "Devonu lug'otit turk" shows that some of the comments on this subject, the linguistic arguments cited, the issues of speech culture and speech etiquette have been raised since ancient times.

E. Begmatov, a well-known researcher of speech culture, writes: “... In Mahmud Kashgari's famous "Devoni lug'atit turk" we come across aphorisms such as, "it is 
impossible to understand the word "kuy" (a melody or to burn), a hard stone cannot be broken", "if a person enjoys the sweetness of the word, he becomes captured by the word", "Language is the beginning of manners"..." [1].

The issue of speech etiquette is covered in the work of the great Khorezmian scholar AbulQasim Mahmud ibn Umar az-Zamahshari, who lived and worked in the XI century, his work was entitled "Nawabig ul-kalim" ("Delicate phrases").

\section{THE MAIN PART}

Speaking at a beautiful and artistic level is also an art of keeping a short, meaningful speech etiquette in terms of content. In ancient times, the art of public speaking in the East was called "va'z" (oratory speech). The word "va'z" in Arabic means oratory, admonition, and the word "voiz" means a person who speaks eloquently.

Until the ninth century, caliphs and shahs served as orators in the East.

From the ninth century onwards, the rulers of the state entrusted this event to the masters of special words at their disposal, adding the word "Voiz" (orator) to their names.

Since the twelfth century, many scientific, historical, methodological treatises have been written that interpret and describe the theory and practice of the art of oratory. These include Muhammad Rafiq Waiz's "Avbob ul-Inan” (The Science of Belief), Waiz Qazvini's "Zilolu Makal” (Pure Proverbs), Waiz Shirvani's "Ahsan ul-Ahodith" (The best event), Muhammad Waiz's "Hidayat ul-Taqwim" (The right way of the period), Quraysh Saidi's "Anis ul-Waizin" (The friend of Waizs), Waiz Samarkandiy's “Ravzat ul-voizin” (The garden of Waizs), Qazi Oshiy's “Miftoq ul-najjih" (The key of knowledge), Waiz Kashifi's "Dah Majlis" (The meeting), "Mahzan ul-insho" (The treasure of writings). The works of historians, poets, and hadith scholars also contain some ideas related to the art of oratory.

Alisher Navoi, the sultan of the realm of speech, was also seriously concerned with the culture of speech and the art of oratory. During the reign of Alisher Navoi, the status of the Uzbek language and the art of public speaking rose to a higher level. Alisher Navoi devoted chapter 24 of his work "Mahbubul-qulub" to oratory. In this work, the speech skills of dozens of orators, such as Hodja Muayyad Mehnagiy, Mawlana Riyazi, Mawlana Irshad, Hotam Asom, Voiz Kashifi, Muin Voiz, are mentioned.

At that time, those who were engaged in the art of oratory and related fields were called "nadims, narrators, storytellers, badihagoys, reciters, problem-solvers, orators, waizs, guyandas, maddahs and ode-tellers"[2].

The art of oratory came in three main forms: dabirlik (the writers and readers of the state correspondence), xatiblik (speakers of religious, political speech), and muzakkirlik (speakers of religious and moral issues). Dabirlik meant the recitation of state correspondence, khatiblik meant reading khutba (sermon), and muzakkirlik meant to make speeches on Fridays, Eid and other ceremonies.

The art of oratory was divided into three, taking into account the socio-political status and positions of listeners, orators, and other features: sultanate - for high-ranking officials; jihadiya -for participants of the war; garibona speeches addressed to ordinary citizens. The writing and reading of each type, as well as the conditions and method of oratory, were different. 
The issue of the need to seriously address the problems of speech and speech culture on a scientific basis was first raised by representatives of the Prague Linguistic Circle. They paid special attention to this issue in their special theses and subsequent works prepared for the First Congress of the Slavs in Prague in 1929.

The scientific views of the Prague Linguistic Circle on the culture of speech and the literary norm are analyzed in detail in some of $\mathrm{E}$. Begmatov's works. He came to the conclusion from his analysis: "The views put forward by the Prague Linguistic Circle on Literary Language, Literary Norms and Speech Culture can be said to be a general law for all folk literary languages. In turn, this doctrine can be a program for the scientific solution of a number of issues of the Uzbek literary language and Uzbek speech culture ..." [3].

Nowadays, the culture of speech and oratory occupy a special place in the attention of scholars from different countries of the world, including America, England, Japan, Germany. Examples include the works of Pol. L.Soper, Edgar I.Willis, D.Karnegi, M. Berkeley-Allen, Chris Steward, and Mike Wilkinson. [4]

The study of this issue as an independent branch of linguistics began in Russian linguistics in the 20-30s.

In 1920, the Institute of “Expressive Speech", an oratory school in Petrograd, began its work. Shortly afterwards, rhetoric courses will be opened in Moscow, as well as a number of studies on this problem by V.A. Artyomov, V.V. Vinogradov, K.I. Chukovsky, L.V. Uspensky, D.E. Rosenthal et al appeared. In the 60s and 70s, the socio-linguistic approach to the art of public speaking is described in monographs by a number of scientists, including E.A. Adamov, L.P. Grossman, A.I. Efimov, A.F. Koni, A.F. Losev, E.A.Nojin, A. Spirkin, E.M.Yaroslavsky, which indicates that the problem is becoming a topical issue [5]. The researches of Russian linguists on speech culture were analyzed in detail in some works of E. Begmatov. Because of this, we will not dwell on this issue too much.

Serious attention to the problems of speech culture and rhetoric in Uzbek linguistics was emphasized at the 1st Republican Conference in 1969 in Tashkent. Unfortunately, no serious attention has been paid to the theoretical study of the Uzbek language in the work on the culture of speech and the art of oratory, the method of oratory. Uzbek linguists, including E. Begmatov, S. Inomkhodjaev, L. Khodjaeva, T. Kudratov, H. Jalilov, R. Kungurov, Y.Tojiyeb, B.Urinboev, A.Soliev, M.Mukarramov conducted researches on oratory. Nevertheless, "the study of the similarities and differences between the concepts of speech culture and oratory, the art of oratory, defining the place and role of speech culture in the art of oratory" remains one of the pressing issues.

Linguistic-methodological features of oratory are one of the problems of methodological science, which is not yet fully theoretically substantiated, and a complete manual on the linguistic-methodological practice of oratory has not yet been created. Until now, in Uzbek philology, oratory has been considered as an art, its social direction has been studied, and its features have not been described in linguistic terms.

There are specific linguistic units and tools of the art of oratory, and these tools create the art of oratory. One of the current issues is to prove the importance of linguistic and methodological means of speech in the emergence of the art of oratory.

Enjoying the incomparable power of the expressive word is one of the characteristics of the Uzbek people. Oratory is the science of beautiful and impressive speech, the art of 
artistically mature speaking. The speech is rich in evidence, and its main functions are:

1. To prove one's point of view, that is, to prove the accuracy of the evidence presented;

2. Giving aesthetic pleasure to the audience;

3. Influence the minds, hearts and moods of the audience, encourage people to be active.

As noted, the art of live speech has been given special attention since ancient times. Nowadays, there is a great demand for people in this field. The speaker has the task of improving and perfecting the quality of his speech. In the successful speech, the formal aspect of the speech is also of great importance.

For a speech to be effective, it must have clear and distinct pronunciation, correct, well-placed pauses. Special attention should also be paid to speech speed, volume, breathing, consistent communication with the audience, hand movements, and similar non-verbal and other linguistic means.

The culture of speech includes the skillful use of language resources, the application of them in accordance with the content of the text, the ability to subordinate them to the main goals and objectives. Speech combines features such as logic, expressiveness, imagery, emotionality, and thus persuasiveness.

Rhetorical question-and-answer, honourable words and phrases, colorful words, addressing, and a number of other methods are used in oratory public speaking.

The use of the rhetorical question method is important in establishing communication between the listener and the speaker. The use of this method encourages the audience to think about the topic of the speech. For example, the rhetorical question such as, "Who doesn't love life?! Who doesn't enjoy it?"

Oratory is a speaking skill, as well as a unique ability. In order to acquire speaking skills, a speaker must first set and follow these requirements. Each speaker must work on himself and improve his speaking skills. Mark Tully Cicero, one of the most famous orators of ancient Rome, said: "A man is born a poet, he grows up to be a speaker."

According to Cicero, the requirements for a speaker are:

1. The speaker should be bold in the speech process, have a deep knowledge of the topic of speech;

2. The speech must be fully proven;

3. Speech should be free from clichés and insignificant thoughts;

4. Careful collection of speech materials should arouse interest in the audience with their topic;

5. Placement of resources according to a plan should be easy to understand.

The speaker must be able to find his listener and focus on his words, it all depends on what the speaker is saying, what he is thinking: "Do not say a word in vain, a word in vain is the word of a madman. If you want to speak to everyone, see if he is a buyer (listener) of your words, say a word that pleases the listener, so that he will be a buyer (listener) of your word."

From the abovementioned, we can conclude that, oratory is a true speech perfection, characterized by lexical, grammatical, syntactic and non-linguistic means, free from lexical, syntactic defects, logical complexity and confusion, with specific pronunciation, tone, rhetorical forms.

Live speech is the essence of the art of speech. 
For speech to be fluent and successful, the speaker must have mastered the expressive means of speech. Expressiveness, on the other hand, is a clear and distinct pronunciation, the right tone, a well-placed pause, and a lively dialogue with the audience.

Every speaker should be distinguished by his style of speech and behavior. That is, it must have its own independent style. For example, one speaker can captivate the listener by finding and speaking compelling words, another by proving his point with evidence, and a third speaker can captivate the listener with his emotional interpretation.

Impressive words, arguments, and emotional interpretation are the three main characteristics of oratory.

Critically mastering the best examples of past speakers added to the art of public speaking and making effective use of their experiences is an important way to master public speaking skills.

Oratory is an art soaked in the blood of our people. Hodja Muayyad Mehnagi, Mawlana Riyazi, Muin Waiz, Qazi Oshi, Husayn Waiz Kashifi, Abul-Qasim Mahmud az-Zamahshari, Mawlana Irshad, Hotam Asom and other such eloquent speakers from the past have made a great contribution to the development of oratory.

In the East, including in the Movaraunnahr region, much work has been done and information has been collected on the importance, meaning and purposeful use of the word in conjunction with the development of artistic and scientific creativity, as well as preaching and the promotion of the Qur'an. As a result of the growth of oratory, the requirements for speech became more perfect.
The great scholars Abu Rayhan al-Biruni, Abu Nasr al-Farabi, Ibn Sina, Abu Abdullah alKhwarizmi, Mahmud Kashgari, Kayvokus, Yusuf Khas Hajib, and Ahmad Yugnaki wrote works on language, vocabulary, grammar, and logic, and expressed their views on the subject.

The great encyclopedic scholar Aburayhan Beruni (973-1048) in the introductory part of his work "Geodesy" speaks about the emergence and branching of sciences, noting that the structure of human speech is controversial, there are two types of speech prose and poetry.

In his book "Classification of Sciences", Abu Nasr al-Farabi (870-950) explains the importance of lexicology, grammar and logic in correct speech, logical conclusions, meaningful and beautiful speech.

According to Farobi, the sciences and the knowledge of being in general, it is precisely from the being that, as a result of man's growing need for them and his long study of being, he accumulates evidence in a consistent manner. In the Farobi's system, the various sciences do not deny or exclude each other, but form a single ring that serves to know each other and the world, as well as to achieve happiness.

The two great scholars, Beruni and Farobi, appealed to ancient Greek philosophy, analyzed works of other sciences, reasoned, and wrote down their conclusions and commentaries.

The X-XI centuries were a fruitful period in the development of world culture, in the history of the peoples of Turkestan. In Khorasan, Movarounnahr and Khorezm, great political, cultural, socio-economic, enlightenment changes took place, science rose to the top. Bright works have been created that disturb the science of Turkestan, both artistically and 
spiritually. During this period, artistic speech was highly developed, and its theory was perfectly elaborated.

Abu Abdullah al-Khorazmi (death in 997) in his work "Mafatih-ul-Ulum" (The Key of Knowledge) provided information about some issues of the culture of speech of that time office papers, forms, terms used, terms of literary science and their definition. In this work, al-Khorazmi also talks about the means of artistic expression, their types and qualities.

Another wonderful gift of the XI century is "Kobusnoma". In this rare work, too, great attention is paid to the issue of speech etiquette and culture, and wise words and valuable thoughts are expressed.

"Kobusnoma" was written by Kaikovus in 10821083 and consists of 44 chapters. Kaikovus dedicates his work to his son. He writes about it: "Pisaram man pir shudam" (Meaning: " I dedicated this book to my son"). The work was written as an exhortation to his child, urging him to speak pleasantly, appropriately, not to speak in vain. Chapters 6-7 of the work are about knowledge, etiquette, eloquence:

"... Know that the craft of words is better than all other trades, because, .. man is ten degrees superior to other animals, and this advantage is present in the human body; the five appear on the outside of the human body and the other five are hidden inside; these are: memorizing something, always remembering, imagining, being able to distinguish, and speaking... If your speech does not contain something useful, it is better not to say such a word. Scholars say that the word is a wine, from which a headache (humor) arises, and the word is itself a cure for a headache." Kaikovus learnt to speak well and politely, and exhorted to make it a habit, and to make the tongue and the heart think in the same way. According to him, "Speak the word in its proper place, a word that is not uttered in its proper place, even if it is a good word, it will look bad." [6]

One of the factors that determines a person's morality is his word, his speech. In his work, Kaikovus states: "O child! Know the face and back of the word, follow them, speak meaningfully when you speak, this is a sign of eloquence. If you don't know what the word means when you speak, you look like a bird, such a bird is called a parrot!"

Kaikovus emphasizes that a person should be an orator, and states that the words of a speaker should not be incomprehensible and dry: "...We call such someone a speaker, whose every word should be understood by the people and every word of him should be known to him. Know that the word is very valuable because the word is not everything. Use what you know in the right place..."

The speaker should think about every word and think slowly: "Be moderate in everything you do. Be patient in uttering every word and doing every deed, and avoid haste..." The author urges us not to distort the words of the language, but to adhere to the existing norms of language at all times: "Even if you know the word and the science well, do not distort any word, correctly describe. Say the word in its way."

The author urges the speaker to be humble, because he is perfected by humility: "My child, no matter how eloquent you may be, keep yourself inferior to those who know you, so that you will not become idle in the time of knowledge of the word.To become a speaker, you need to learn a lot, hear useful words, spend more time in a useful oral conversation:

"Do not avoid from hearing words, a person becomes a speaker by hearing words ... If a child does not hear someone's words, he 
becomes dumb. In time, when he hears and learns, he becomes a speaker."

In short, the work "Kobusnoma" has not lost its value even today. Kaikovus advises not only to speak, but also to listen to the words of others, and emphasizes the need to learn from their speech, thus encouraging them to be good orators.

"Kobusnoma" is a work that covers vital and practical issues. It is one of the mature works of scientific and enlightenment significance, which proves these problems with stories, proverbs, and the wise sayings of sages.

Another great scholar who contributed to the development of oratory was the scholar AbulQasim Mahmud ibn Umar ibn Muhammad azZamahshari, who was born and raised in the village of Zamakhshar in Khorezm.

Al-Zamahshari was the author of more than fifty works on linguistics, lexicography, methodology, literature, jurisprudence, hadith, tafsir, recitation, geography, such as "AlQustos”, “Asos ul-Baloga”, "Samiym ularabiya", "Muqaddimat ul-adab", "Maqomat az-Zamahshari”, "Diyvan ush-she'r", "AlKashshof". He also took his place in the field of oratory, he was a well-known scholar of his time and the noble man who created the work known as "Nawabig ul-kalim".

Mahmud az-Zamahshari is one of the famous orators who took his place in the speech of praise. When he finished the hymns and read them, the audience was moved. The hymns written by Zamakhshari are perfect in content and tell the stories that reveal the human qualities of the rulers. Mawlana az-Zamahshari wrote hymns mainly to the rulers of the countries where he was traveling. For example, in his work "Muqaddimat ul-adab", there is a hymn that shows the care of Khorezmshah
Atsiz (he ruled from 521 to $551 \mathrm{AC}$ ) for scholars and writers.

Ibn al-Kiftiy, a historian of that time, described Zamahshari's talent: “... az-Zamahshari was an exemplary scholar in the field of knowledgepoliteness, grammar and vocabulary. He met many great scientists and scholars throughout his life. He has many works on tafsir (explanation of Qur'an), hadith, grammar and other fields. He is the greatest of the non-Arabs who wrote in Arabic in his century."

Az-Zamahshari was very demanding of himself and felt a great responsibility. He encouraged others to do the same. He advised not to rush when doing something and to speak briefly but meaningfully when speaking: "When you start thinking about an issue, do not rush, think in all directions, act politely, think carefully", "Too much talk hurts the listener."

Mawlana Zamakhshari was a great scientist, enlightener and scientist. He advises his interlocutor to be a simple peer. In summary, it is our sacred duty to study the legacy of Mawlana az-Zamahshari.

\section{REFERENCES}

1. Aripova A. Oratory and its linguisticmethodological means. - Tashkent: UWED, 2007. - P.40-45.

2. Methods, aspects and components of teaching the uzbek (russian) language as a foreign language on the experience of foreign students// Aziza Aripova, Khurshida Khodjayeva, Nozima Yuldasheva// Journal of Critical Reviews//2020, P.393-398.

3. Begmatov E. The emergence and substantiation of the problem of speech culture.-T .: Science, 1973.

4. Adamov. E.A. Outstanding speakers of the world. -M., 1961; Grossman L. On the art of the lecturer. -M., 1970; Efimov A.O. culture 
The American Journal of Social Science and Education Innovations (ISSN - 2689-100x)

Published: August 31, 2021 | Pages: 46-53

Doi : https://doi.org/10.37547/tajssei/Volume03Issue08-11

2021: 5.857

of speech. -M., 1956; Koni A. Fav. manu. M., 1959; Losev A. On oratory. 1965; Nozhin E. Fundamentals of public speaking. -M., 1973;

5. A.Aripova. The ideal appearance of a modern teacher/l ACADEMICIA: An International Multidisciplinary Research Journal// 2020.

6. Begmatov E. The emergence and substantiation of the problem of speech culture.-T .: Science, 1973. 